\title{
DISSIPATION OF ENERGY IN TISSUES OF BERRY FRUIT OF SELECTED PLANTS SPECIES UNDER CYCLIC LOAD CONDITIONS
}

\author{
Jerzy Bohdziewicz , Gabriel Czachor \\ Department of Agricultural Engineering, Wroclaw University of Environmental and Life Sciences \\ *Corresponding author: e-mail: jerzy.bohdziewicz@up.wroc.pl \\ ARTICLE INFO \\ Article history: \\ Received: January 2016 \\ Received in the revised form: \\ June 2016 \\ Accepted: July 2016 \\ Key words: \\ mechanical properties, \\ hysteresis loop \\ energy dissipation \\ berries fruits

\begin{abstract}
Dissipation hypothesis of energy under cyclic loads conditions was used to characterize the behavior of berry fruit. The possibility of dissipation of energy as a result of plastic deformations (Dawidenkow hypothesis) or visco-elastic deformations (Voigt hypothesis) was considered. Tests of hysteresis of whole fruit squeezed among two rigid plates for various levels of load and with various speeds of deformation of samples for two directions of load application were conducted for verification of the usefulness of both hypotheses. The strength tests were preceded by the test of hysteresis, the mass and the geometry of fruit were determined additionally as well as conventional density and moisture was counted. A mutual relation of average values of the coefficients of elasticity $E_{C}$ was accepted as the measure of dissipation of energy as a result of changes in the angle of inclination of the curve in the springy return phase. Voigt hypothesis was confirmed as useful within the range of small speeds of deformation and
\end{abstract} \\ lack of usefulness of the Dawidenkow hypothesis was proved.
}

\section{Introduction}

During harvesting, sorting and transportation of fruit various kinds of loads are formed, including dynamic ones. The springy forces which occur with the cyclic load changes aim at the decrease of the displacement speed and cause dissipation of kinetic energy. The forces of the viscous friction are also present. The kinetic energy of mass (the resistance of inertia) of the body can be disregarded for low speeds of deformation.

Rheological models take into account division into solid bodies and liquids. Flowing under the invariable volume is taken into consideration in reference to fruit tissues after they cross the border of plasticity. Springy energy is accumulated under the conditions of quasi-static cyclic load. The quantity of accumulated energy results from the expenditures of work under load and it is the function of acting forces. The total stress inside such a body depends on the history of deformation, contrary to liquid. According to a definition, accumulated springy energy enables realization of the work. The change of deformation and the change of the coefficient of elasticity $E_{C}$ value under the cyclic loads conditions can be considered as the measure of dissipation of this energy. The changes of the deformation 
value as a function of time enable forecasts of the moment when mechanical damages appear.

A berry fruit is an example of the folded structure in which the springy coat surrounds tissues with gel consistency. In order to characterize the behavior of such material one can use the hypothesis of the energy dissipation under the cyclic load conditions (Szczepański et al., 1984). Dawidenkow hypothesis, related to dissipation of energy as a result of plastic deformations, was considered, which depends on the amplitude of deformations and does not depend on the speed (frequency) of deformation. Opposed to it is the Voigt hypothesis relating to visco-elastic dissipation of energy which is independent from amplitude of stresses and depends on the deforming speed.

Barrett at al., (1998) carried out five kinds of compression tests of fruits squeezed among two plates. A wide range of investigations is required to assign a method which would enable differentiation between hard and soft tomato fruits.

Babarinsa and Ige (2012) carried out the compression test of tomatoes with the speed of $2.5 \mathrm{~mm} \cdot \mathrm{s}^{-1}$, the value of stress in the break point was $0.008 \mathrm{MPa}$. Similarly as Letaief (2008) they affirmed that fruit skin of tomato played the main role in ensuring the fruit strength.

Tomatoes subjected to excessive vibration will be easily inflicted with mechanical damage. Available techniques of testing of the strength of tomato fruit were used in investigations conducted by Rajapur et al., (2004). The short strip of berry skin was fixed between jaws and pulled to the moment of failure. Values of failure stress from 8.5 to $10.2 \mathrm{MPa}$ were recorded.

Antonio (2009) stated that destruction of fruit structure due to the shear stress resulted from the decrease of moisture. Changes of shear stress values prove the presence of tixotropy and purees of the fruits have the pseudo-plastic behavior.

Eight mechanical parameters in a double cycle of compression test TPA on wine-grape fruit were determined by Rolle et al. (2012). These parameters were connected to the size of area under force/strain curve; the forces of cohesion and the strength of internal bonds inside berries were calculated.

(Morris, 1983) presented pseudo-plastic behavior of fruits purees such as: raspberries, strawberries, plums, peaches and blueberries.

\section{Objective, scope and methodology}

Recognition of behavior of berries of the selected species of plants in cyclic changes of load conditions was the aim of this investigation. To define material properties based on the accepted hypotheses it is indispensable to determine the degree of energy based on the mutual relations of the apparent coefficient of elasticity values in the load and unload phases under the set conditions of cyclic loads.

Ten iterations of strength test were carried out to characterize mechanical features of each of the selected species of plant berries squeezed between two rigid plates. Average values of force $F_{\max }$ corresponding to the temporary strength were calculated. Differentiation of the shape in the longitudinal and perpendicular axis direction of fruit during tests was considered. 
Dissipation of energy...

During verification of the usefulness of the received hypotheses in reference to berries, five iterations of the hysteresis test under cyclic loads for $3 ; 30$ and $300 \mathrm{~mm} \cdot \mathrm{s}^{-1}$ of deformation speed and with the load of 20; 40; and 60\% level of determined value of $F_{\max }$ force were carried out. The object of investigation consisted of: table-grape Red Globe var. as well as blackcurrant Ojebyn var. and cherry tomatoes. The fruit were sorted in relation to the sphere-like shape and similar size for specific species. The conventional density and the moisture of the studied material were determined additionally.

The strength machine Instron 5566 type with the load cell strain gauge 2525-806 with the range of $1 \mathrm{kN}$ was used for investigations.

The expenditures of unit work of deformation $W_{P}$ during compression of fruit were measured. The equation was used for calculations:

$$
W_{p}=\frac{W}{m}\left(\mathrm{~J} \cdot \mathrm{kg}^{-1}\right)
$$

where:

$W \quad$ - work of deformation

$m$ - mass of fruit

The value of the apparent coefficient of elasticity $E_{C}$ was counted based on the equation (Bohdziewicz et al., 2013):

$$
E_{C}=\frac{\xi \cdot \int_{0}^{F \max } F_{(\lambda)} \cdot \mathrm{d} \lambda}{\varepsilon^{2}}
$$

where:

$$
\begin{aligned}
& F_{(\lambda)}-\text { measured force } \\
& \xi-\text { coefficient taking into account the fruit size } \\
& \varepsilon-\text { relative deformation in the direction of the acting load } \\
& \mathrm{d} \lambda-\text { displacement }
\end{aligned}
$$

The average values of the apparent coefficient of elasticity in the load phase of first hysteresis loop was marked as $E_{\mathrm{Cl}}$ and depend on the expenditures of the deformation work, whereas these marked as $E_{\mathrm{Cu}}$ depend on the accumulated energy in the third hysteresis loop. The mutual relation of both coefficients values is the measure of dissipation of energy:

$$
\chi=\frac{E_{C l}}{E_{C u}}
$$

\section{Results and discussion}

The results of the measurements of physical properties as well as the break forces values of tested material were presented in table 1 .

To confirm the assumption that the dissipation of energy in the material results from plastic deformations the Dawidenkow hypothesis was used. The hysteresis tests were used to use to verify the different levels of load but at similar speed of cycles. Tables 2 and 3 
Jerzy Bohdziewicz, Gabriel Czachor

present a comparison of changes values of mechanical properties of grape and tomato berries in individual phases of hysteresis cycles with the load in axial direction.

Table 1.

Compilation of average values of selected physical properties and break forces of studied material

\begin{tabular}{lccccc}
\hline Material & $\begin{array}{c}\text { Mass (SD) } \\
(\mathrm{g})\end{array}$ & $\begin{array}{c}\text { Moisture (SD) } \\
(\%)\end{array}$ & $\begin{array}{c}\text { Density (SD) } \\
\left(\mathrm{kg} \cdot \mathrm{m}^{-3}\right)\end{array}$ & $\begin{array}{c}\text { Axial force } \\
F_{\max },(\mathrm{N})\end{array}$ & $\begin{array}{c}\text { Radial force } \\
F_{\max },(\mathrm{N})\end{array}$ \\
\hline Grapefruit & $12.5(0.7)$ & $83 \%(3 \%)$ & $1235(46)$ & $51.1(6.3)$ & $38.3(5.8)$ \\
Tomato & $10.3(0.6)$ & $94 \%(2 \%)$ & $1140(32)$ & $17.9(2.7)$ & $26.2(4.5)$ \\
Blackcurrant & $2.9(0.4)$ & $86 \%(2 \%)$ & $1165(51)$ & $13.1(2.2)$ & $6.7(0.8)$ \\
\hline
\end{tabular}

Table 2.

Average values and standard deviation (SD) of mechanical properties; hysteresis test of grape berries for various levels of load

\begin{tabular}{lcccc}
\hline Tests conditions & $\begin{array}{c}\text { Modulus } E_{C} \\
(\mathrm{MPa})\end{array}$ & $\begin{array}{c}\text { Strain } \varepsilon \\
(-)\end{array}$ & $\begin{array}{c}\text { Coefficient } W_{p} \\
\left(\mathrm{~J} \cdot \mathrm{kg}^{-1}\right)\end{array}$ & $\begin{array}{c}\text { Stress } \sigma \\
(\mathrm{MPa})\end{array}$ \\
\hline Load, first loop, 20\% $F_{\max }$ & $0.16(0.02)$ & $0.086(0.011)$ & $0.23(0.03)$ & $0.013(0.002)$ \\
Unload, first loop, 20\% $F_{\max }$ & $0.32(0.04)$ & $0.029(0.003)$ & $0.05(0.01)$ & $0.008(0.001)$ \\
Load, third loop, 20\% $F_{\max }$ & $0.44(0.06)$ & $0.031(0.004)$ & $0.09(0.01)$ & $0.013(0.002)$ \\
Unload, third loop, 20\% $F_{\max }$ & $0.34(0.04)$ & $0.027(0.003)$ & $0.05(0.01)$ & $0.008(0.001)$ \\
\hline Load, first loop, 40\% $F_{\max }$ & $0.14(0.03)$ & $0.189(0.039)$ & $1.09(0.25)$ & $0.027(0.004)$ \\
Unload, first loop, 40\% $F_{\max }$ & $0.37(0.04)$ & $0.049(0.008)$ & $0.17(0.04)$ & $0.016(0.003)$ \\
Load, third loop, $40 \% F_{\max }$ & $0.51(0.10)$ & $0.054(0.012)$ & $0.31(0.07)$ & $0.027(0.006)$ \\
Unload, third loop, $40 \% F_{\max }$ & $0.36(0.06)$ & $0.046(0.008)$ & $0.16(0.03)$ & $0.016(0.003)$ \\
\hline Load, first loop, $60 \% F_{\max }$ & $0.14(0.03)$ & $0.269(0.062)$ & $2.16(0.51)$ & $0.038(0.008)$ \\
Unload, first loop, 60\% $F_{\max }$ & $0.28(0.06)$ & $0.076(0.018)$ & $0.46(0.12)$ & $0.020(0.004)$ \\
Load, third loop, 60\% $F_{\max }$ & $0.45(0.10)$ & $0.081(0.018)$ & $0.610 .12)$ & $0.036(0.007)$ \\
Unload, third loop, $60 \% F_{\max }$ & $0.29(0.06)$ & $0.072(0.015)$ & $0.32(0.07)$ & $0.021(0.004)$ \\
\hline
\end{tabular}

Table 3.

Average values and the standard deviation (SD) of mechanical properties; hysteresis test of tomato berries for various levels of load

\begin{tabular}{lcccc}
\hline Tests conditions & $\begin{array}{c}\text { Modulus } E_{C} \\
(\mathrm{MPa})\end{array}$ & $\begin{array}{c}\text { Strain } \varepsilon \\
(-)\end{array}$ & $\begin{array}{c}\text { Coefficient } W_{p} \\
\left(\mathrm{~J} \cdot \mathrm{kg}^{-1}\right)\end{array}$ & $\begin{array}{c}\text { Stress } \sigma \\
(\mathrm{MPa})\end{array}$ \\
\hline Load, first loop, 20\% $F_{\max }$ & $0.10(0.02)$ & $0.084(0.016)$ & $0.29(0.04)$ & $0.008(0.001)$ \\
Unload, first loop, 20\% $F_{\max }$ & $0.25(0.04)$ & $0.025(0.004)$ & $0.06(0.01)$ & $0.006(0.001)$ \\
Load, third loop, 20\% $F_{\max }$ & $0.50(0.08)$ & $0.035(0.007)$ & $0.12(0.02)$ & $0.012(0.002)$ \\
Unload, third loop, 20\% $F_{\max }$ & $0.36(0.06)$ & $0.028(0.005)$ & $0.05(0.01)$ & $0.005(0.001)$ \\
\hline Load, first loop, 40\% $F_{\max }$ & $0.14(0.03)$ & $0.128(0.033)$ & $0.99(0.24)$ & $0.018(0.004)$ \\
Unload, first loop, 40\% $F_{\max }$ & $0.34(0.08)$ & $0.033(0.009)$ & $0.16(0.04)$ & $0.011(0.002)$ \\
Load, third loop, 40\% $F_{\max }$ & $0.51(0.12)$ & $0.036(0.009)$ & $0.28(0.08)$ & $0.018(0.004)$ \\
Unload, third loop, 40\% $F_{\max }$ & $0.36(0.08)$ & $0.031(0.008)$ & $0.15(0.04)$ & $0.011(0.003)$ \\
\hline
\end{tabular}


Dissipation of energy...

\begin{tabular}{lllll}
\hline Load, first loop, $60 \% F_{\max }$ & $0.14(0.03)$ & $0.221(0.058)$ & $2.61(0.76)$ & $0.031(0.009)$ \\
Unload, first loop, 60\% $F_{\max }$ & $0.37(0.10)$ & $0.047(0.013)$ & $0.36(0.12)$ & $0.017(0.005)$ \\
Load, third loop, $60 \% F_{\max }$ & $0.56(0.15)$ & $0.053(0.015)$ & $0.66(0.21)$ & $0.031(0.009)$ \\
Unload, third loop, $60 \% F_{\max }$ & $0.41(0.11)$ & $0.047(0.012)$ & $0.34(0.11)$ & $0.017(0.004)$ \\
\hline
\end{tabular}

The results of calculations of the coefficient of elasticity $E_{C}$ of tomato berries (table 3 ) are convergent with the results of investigations of cherry tomatoes carried out by Mahmoodi-Eshkaftaki and Maleki (2013). They tested five varieties of fruit in three degrees of maturity; modulus of elasticity was from 0.1765 to $0.1036 \mathrm{MPa}$ and the calculated value was $\mathrm{E}=0.18 \mathrm{MPa}$ for modeled cherry tomatoes fruits with the method of finite elements.

The results of calculations of coefficient $\varkappa$ values for both directions of load application was put together on graphs 1 and 2 .

Differentiation of values of the coefficient $\varkappa$ is not considerable on both graphs and is within the range of computational errors. It means that that dissipation of energy during cyclic loads has the similar course independently from the level of load and strain and taking into account the linear relation force-displacement also from the deformation. It may be the basis for the rejection of hypothesis on the plastic character of observed deformations.

The hysteresis tests for three speeds of load application were carried out in order to verify the usefulness of Voigt hypothesis. The examples of comparison of average values of coefficients characterizing mechanical properties of grape berries were put in table 4 , whereas for tomato berries in table 5 .

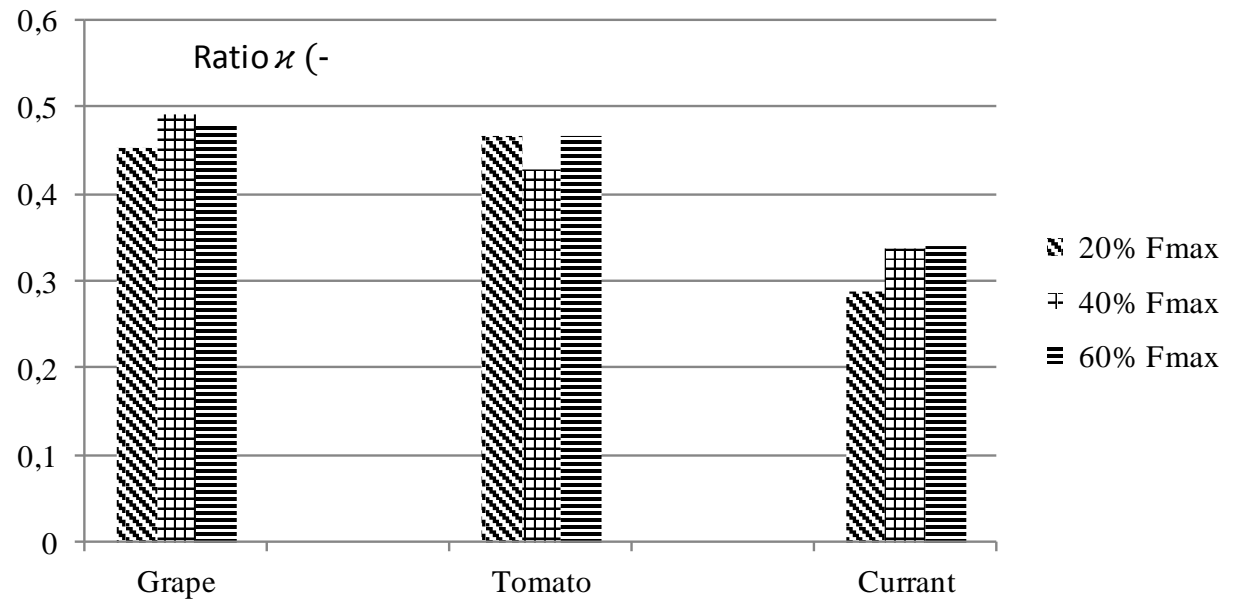

Figure 1. Compilation values of ratio $\varkappa$ of tested material; hysteresis test for longitude axis direction of load 


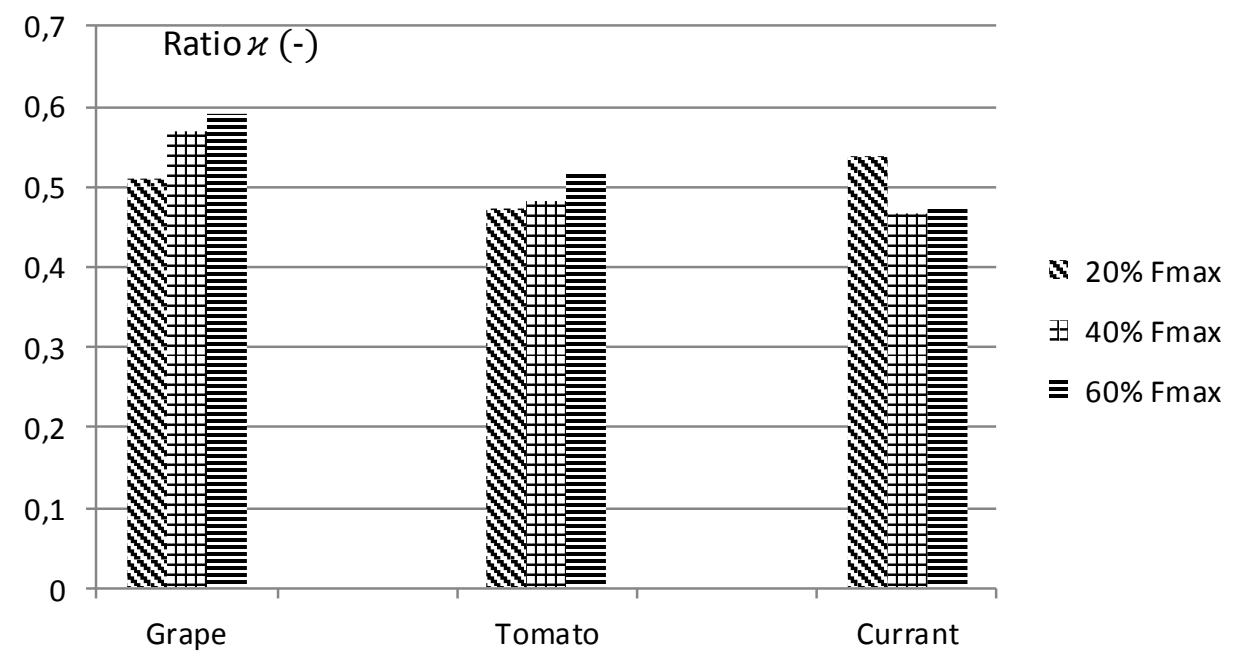

Figure 2. Compilation calculations of ratio $\varkappa$ values of tested material; hysteresis test for radial direction of load

Table 4.

Average values and standard deviation (SD) of selected mechanical properties of grape berries, the hysteresis test with load $25 \% F_{\max }$ for various speeds of deformation

\begin{tabular}{lcccc}
\hline Tests conditions & $\begin{array}{c}\text { Modulus } E_{C} \\
(\mathrm{MPa})\end{array}$ & $\begin{array}{c}\text { Strain } \varepsilon \\
(-)\end{array}$ & $\begin{array}{c}\text { Coefficient } W_{p} \\
\left(\mathrm{~J} \cdot \mathrm{kg}^{-1}\right)\end{array}$ & $\begin{array}{c}\text { Stress } \sigma \\
(\mathrm{MPa})\end{array}$ \\
\hline Load, first loop, 3 $\mathrm{mm} \cdot \mathrm{min}^{-1}$ & $0.10(0.03)$ & $0.170(0.034)$ & $3.43(0.88)$ & $0.018(0.007)$ \\
Unload, first loop, 3 $\mathrm{mm} \cdot \mathrm{min}^{-1}$ & $0.20(0.04)$ & $0.059(0.008)$ & $0.58(0.12)$ & $0.012(0.006)$ \\
Load, third loop, 3 $\mathrm{mm} \cdot \mathrm{min}^{-1}$ & $0.28(0.04)$ & $0.069(0.007)$ & $1.10(0.22)$ & $0.019(0.008)$ \\
Unload, third loop, 3 $\mathrm{mm} \cdot \mathrm{min}^{-1}$ & $0.24(0.04)$ & $0.055(0.006)$ & $0.70(0.17)$ & $0.013(0.005)$ \\
\hline Load, first loop, 30 $\mathrm{mm} \cdot \mathrm{min}^{-1}$ & $0.17(0.03)$ & $0.208(0.022)$ & $1.90(0.59)$ & $0.036(0.011)$ \\
Unload, first loop, 30 $\mathrm{mm} \cdot \mathrm{min}^{-1}$ & $0.20(0.02)$ & $0.066(0.007)$ & $0.32(0.07)$ & $0.013(0.004)$ \\
Load, third loop, $30 \mathrm{~mm} \cdot \mathrm{min}^{-1}$ & $0.23(0.04)$ & $0.078(0.007)$ & $0.71(0.22)$ & $0.017(0.003)$ \\
Unload, third loop, 30 $\mathrm{mm} \cdot \mathrm{min}^{-1}$ & $0.20(0.02)$ & $0.069(0.007)$ & $0.30(0.06)$ & $0.014(0.002)$ \\
\hline Load, first loop, 300 $\mathrm{mm} \cdot \mathrm{min}^{-1}$, & $0.18(0.03)$ & $0.154(0.021)$ & $1.56(0.49)$ & $0.027(0.009)$ \\
Unload, first loop, $300 \mathrm{~mm} \cdot \mathrm{min}^{-1}$ & $0.19(0.04)$ & $0.066(0.007)$ & $0.47(0.15)$ & $0.012(0.003)$ \\
Load, third loop, $300 \mathrm{~mm} \cdot \mathrm{min}^{-1}$ & $0.25(0.05)$ & $0.071(0.011)$ & $0.71(0.21)$ & $0.017(0.005)$ \\
Unload, third loop, $300 \mathrm{~mm} \cdot \mathrm{min}^{-1}$ & $0.20(0.05)$ & $0.064(0.007)$ & $0.47(0.11)$ & $0.013(0.003)$ \\
\hline
\end{tabular}


Dissipation of energy...

Table 5.

Average values and standard deviation (SD) of selected mechanical properties of tomato berries, the hysteresis test with load of $25 \% F_{\text {max }}$ for various speeds of deformation

\begin{tabular}{lcccc}
\hline Terms of tests realization & $\begin{array}{c}\text { Modulus } E_{C} \\
(\mathrm{MPa})\end{array}$ & $\begin{array}{c}\text { Strain } \varepsilon \\
(-)\end{array}$ & $\begin{array}{c}\text { Coefficient } W_{p} \\
\left(\mathrm{~J} \cdot \mathrm{kg}^{-1}\right)\end{array}$ & $\begin{array}{c}\text { Stress } \sigma \\
(\mathrm{MPa})\end{array}$ \\
\hline Load, first loop, 3 $\mathrm{mm} \cdot \mathrm{min}^{-1}$ & $0.09(0.03)$ & $0.166(0.037)$ & $1.31(0.35)$ & $0.015(0.005)$ \\
Unload, first loop, 3 $\mathrm{mm} \cdot \mathrm{min}^{-1}$ & $0.16(0.03)$ & $0.067(0.012)$ & $0.33(0.09)$ & $0.010(0.002)$ \\
Load, third loop, 3 $\mathrm{mm} \cdot \mathrm{min}^{-1}$ & $0.24(0.07)$ & $0.067(0.013)$ & $0.58(0.13)$ & $0.016(0.006)$ \\
Unload, third loop, 3 $\mathrm{mm} \cdot \mathrm{min}^{-1}$ & $0.19(0.04)$ & $0.062(0.011)$ & $0.32(0.08)$ & $0.012(0.003)$ \\
\hline Load, first loop, 30 $\mathrm{mm} \cdot \mathrm{min}^{-1}$ & $0.10(0.03)$ & $0.175(0.046)$ & $1.72(0.52)$ & $0.018(0.005)$ \\
Unload, first loop, 30 $\mathrm{mm} \cdot \mathrm{min}^{-1}$ & $0.14(0.04)$ & $0.068(0.014)$ & $0.38(0.09)$ & $0.009(0.002)$ \\
Load, third loop, 30 $\mathrm{mm} \cdot \mathrm{min}^{-1}$ & $0.25(0.07)$ & $0.072(0.015)$ & $0.78(0.18)$ & $0.018(0.005)$ \\
Unload, third loop, 30 $\mathrm{mm} \cdot \mathrm{min}^{-1}$ & $0.15(0.04)$ & $0.064(0.012)$ & $0.37(0.11)$ & $0.009(0.002)$ \\
\hline Load, first loop, 300 $\mathrm{mm} \cdot \mathrm{min}^{-1}$, & $0.13(0.02)$ & $0.163(0.035)$ & $1.66(0.38)$ & $0.020(0.003)$ \\
Unload, first loop, 300 $\mathrm{mm} \cdot \mathrm{min}^{-1}$ & $0.17(0.04)$ & $0.070(0.013)$ & $0.60(0.14)$ & $0.012(0.002)$ \\
Load, third loop, 300 $\mathrm{mm} \cdot \mathrm{min}^{-1}$ & $0.18(0.04)$ & $0.112(0.022)$ & $0.79(0.18)$ & $0.014(0.003)$ \\
Unload, third loop, 300 $\mathrm{mm} \cdot \mathrm{min}^{-1}$ & $0.20(0.04)$ & $0.069(0.011)$ & $0.61(0.15)$ & $0.014(0.004)$ \\
\hline
\end{tabular}

Compilation average values of coefficient $\varkappa$ for various speeds of load application were presented on graph 3.

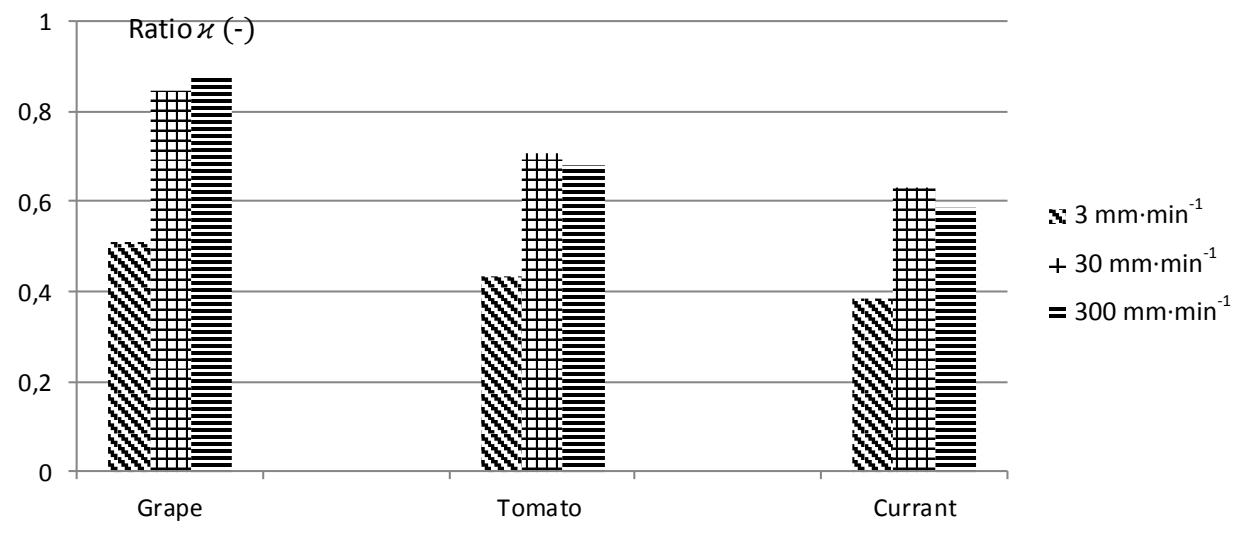

Figure 3. Compilation values of ratio $\varkappa$ of tested material; hysteresis test for longitude axis direction of load

Diversity of values of the coefficient $\varkappa$ in the axis direction of load is noticeable in figure 3 in the range of the smaller speeds of displacement. Analogous connections were found in case of load in radial direction. This testifies the visco-elastic behavior of tested material under cyclic loads according to Voigt hypothesis. In reference to the speed of 300 $\mathrm{mm} \cdot \mathrm{min}^{-1}$ this is not useful. 
To demonstrate the behavior of samples under the cyclic load conditions in figure 4 the examples of relations of force-displacement were presented. The value of coefficient $\varkappa$ is a relation of mutual values of inclination angles in the first and last curve from the set of curves in the hysteresis cycle.
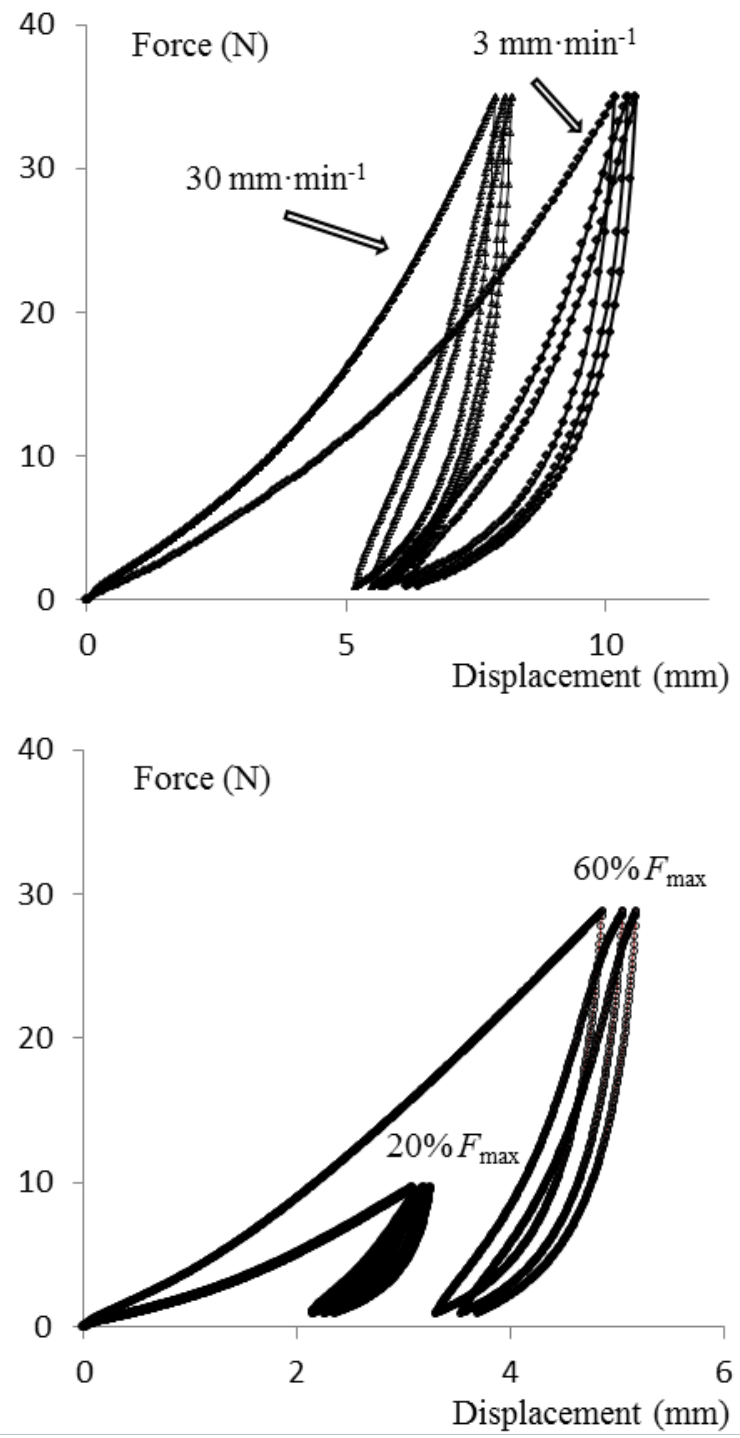

Figure 4. Examples of force-displacement relations; hysteresis test of tomato berries in longitude axis direction of load 
Dissipation of energy...

\section{Conclusions}

The problem of dissipation of springy energy in reference to berry fruit can be explained with regard to Voigt hypothesis. Dissipation of energy is a consequence of mutual slow displacements of the liquid consistency substances in relation to the exodermis structure of the fruit and other solid tissues of the fruit flesh. The growth of resistance in the unload phase is a consequence of the increase of the viscous friction following the growth of the frequency of deformations. This is expressed by the change of mutual relations of values of coefficient $E_{C}$ in the load phase and in the phase of springy return.

Dawidenkow hypothesis is not useful because the growth of expenditures work of deformation at a small degree influences the changes of resistance of deformation in the unload phase. This is independent from the load application direction.

\section{References}

Antonio, G. C. et al. (2009). Rheological behavior of blueberry. Cencia e Tecnologia de Alimentos, 29(4), 732-737.

Babarinsa, F.A., Ige, M.T. (2012). Strength parameters of packaged Roma tomatoes at break point under compressive loading, International Journal of Scientific\&Engineering Research, 3(10), 240-247.

Barret, D.M. et al. (1998). Textural modification of processing tomatoes: critical review, Food Science and Nutrition, 38(3),173-258

Bohdziewicz, J., Czachor, G., Grzemski, P. (2013). Anisotropy of mechanical properties of mushrooms (Agaricus bisporus (j.e. lange)imbach), Agricultural Engineering, 4(148), 281-290.

Letaief, H., et al. (2008). Technical Brief Mechanical Behavior of Wine grapes under Compression Tests. American Journal of Enology and Viticulture, 59(3) 323-329

Mahmoodi-Eshkaftaki, M., Maleki, A. (2013). Simulation of a tomato sample using finite element method, International Journal of Agriculture and Crop scieces, 5(16), 1739-1744.

Morris J. R. (1983), Effect of mechanical harvesting on the quality of small fruits and grapes, Transactions of American Society of Agricutural Engineers, 5(84), 332-348.

Rajabipour, A. et al. (2004). Tensile strength and relaxation of tomato skin by a loop technique. International Agrophysics, 18(2), 153-157.

Rolle, L. et al. (2012). Instrumental texture analysis parameters as markers of table-grape and wine grape quality: a review, American Journal of Enology and Viticulture, 63(1), 11-28.

Szczepański, W. et al. (1984). The experimental methods mechanics of solid body (in polish). PWN Warszawa. ISBN 8301-033819. 
Jerzy Bohdziewicz, Gabriel Czachor

\section{ROZPROSZENIE ENERGII W TKANKACH OWOCÓW JAGODOWYCH WYBRANYCH GATUNKÓW ROŚLIN W WARUNKACH OBCIĄŻENIA CYKLICZNEGO}

Streszczenie. Do scharakteryzowania behawioru owoców jagodowych wykorzystano hipotezy rozproszenia energii przy obciążeniach cyklicznych. Uwzględniono możliwość rozpraszanie energii na skutek odkształceń plastycznych (hipoteza Dawidenkowa) lub odkształceń sprężysto-lepkich (hipoteza Voigta). Do weryfikacji przydatności obu hipotez przeprowadzono testy histerezy całych owoców ściskanych pomiędzy dwiema sztywnymi płytami dla różnych poziomów obciążenia i przy różnych prędkościach odkształcenia próbek dla dwóch kierunków przyłożenia obciążenia. Test histerezy poprzedzono testami wytrzymałościowymi, dodatkowo wyznaczono masę i geometrię owoców, obliczano umowną gęstość i wilgotność. Jako miarę rozproszenia energii przyjęto wzajemną relację średnich wartości współczynników sprężystości $\mathrm{E}_{\mathrm{C}}$ jako skutek zmian kąta nachylenia krzywej w fazie sprężystego powrotu. Stwierdzono przydatność hipotezy Voigta w zakresie niewielkich prędkości odkształcenia i wykazano brak przydatności hipotezy Dawidenkowa.

Słowa kluczowe: właściwości mechaniczne, pętla histerezy, rozproszenie energii, owoce jagodowe 